Management Dynamics

Vol. 23, No. 2: 13-32, 2020

Shanker Dev Campus

Doi: https://doi.org/10.3126/md.v23i2.35801

\title{
Nexus between firm fundamentals and financial leverage in Nepalese non- financial firms
}

\begin{abstract}
This paper aims to analyze the nexus between firm fundamentals and financial leverage in Nepalese non-financial firms for the period 2000/01-2017/18 applying descriptive and causal comparative research design. Short-term, long-term and total financial leverage ratios are dependent variables and firm-fundamental variables are considered as explanatory variables. The result of this paper shows that Nepalese firms are highly levered. Regression results of this study reveals that profitability, earning variability, liquidity are major determinants of financial leverage. This study concludes that shortterm financial leverage is positively affected by growth and earning variability whereas negatively affected by profitability, tangibility, and liquidity of firms. Similarly, long-term financial leverage is positively influenced by size, assets tangibility, and earning variability whereas negatively influenced by profitability and liquidity. Further, result of the paper reveals positive effect of assets tangibility and earning variability and negative effect of profitability and liquidity on total financial leverage. Finally, this paper concludes that firms' non-debt tax shield and age of firms have no significant impact on financial leverage in Nepalese non-financial firms.
\end{abstract}

Keywords: Financial leverage, size, profitability, tangibility, growth, earning variability and liquidity.

\section{Introduction}

The nexus between firm fundamentals and corporate financial leverage has been the most debated and controversial issue for academics and policy makers. Financial structure decision is mostly concerned with composition of debt and equity capital to be financed by a firm, effect of capital structure on stock price and cost of capital, optimal proportion of short-term and long-term financing, use of internal and external financing in business firm, different capital structure of various firms etc. Financial structure varies from one firm to another firm. Though, two firms are similar in nature, operation etc. have no single financial structure, and even a single financial structure cannot be suit for the same firm forever. While developing a financial structure for a firm, financial manager should aim to maximize value of firm by exploiting advantage of favorable financial leverage maintaining optimal capital structure. Theory of financial structure has been passionately debated, discussed and argued since development of theory of capital structure irrelevance of Modigliani and Miller (1958).

* Associate Professor, Shanker Dev Campus, PhD Scholar, Faculty of Management, TU, Nepal. 
Capital structure theory of irrelevance assumes perfect capital markets and concludes leverage of a firm doesn't affect firm's value. Modigliani and Miller (1963) considered taxation and argued that firms should use debt capital as much as possible to achieve tax benefit of leverage. Along with corporate taxation, researchers were interested in analyzing case of personal taxes imposed on individuals. A number of theories have been proposed to explain variations in leverage ratios across firms after landmark studies of Modigliani and Miller (1958 \& 1963). Through theoretical and empirical studies, a number of theories have been proposed to explain variation in leverage ratio across firms. Theory suggests that firms should select optimal capital structure depending on attributes that determine various costs and benefits associated with debt and equity financing of firms. Traditional Trade-off Theory accepts that optimal capital structure involves balancing corporate tax advantages of debt against present value of bankruptcy costs (Kim, 1978; Kraus \& Litzenberger, 1973), and agency costs (Jensen \& Meckling, 1976; Myers, 1977). Pecking Order Theory (Myers, 1984; Myers \& Majluf, 1984) states that there is no defined target debt ratio. Firms are suggested to prefer retained earnings as main sources of financing. Next, firms should prefer to raise funds from less risky sources of debt and finally, firms should raise funds from risky sources of external equity financing. In this way, having such theoretical debates, an important issue is raised to firms in managing new financing requirements whether to rise from debt or equity.

The majority of empirical studies on this issue are based on data from developed countries, mainly from US firms. Number of studies examined capital structure choice of each developing country is limited. However, empirical evidence points out to one general observation using data from developing countries. Study of Singh and Hamid (1992) indicates that firms in developing countries rely on a greater proportion of equity than debt. This finding is supported by the result of Booth et al. (2001). However, empirical evidence regarding alternative theories is still inconclusive (Rajan \& Zinglaes, 1995). Concerning under developing country like Nepal, there is lacking in-depth empirical studies of nexus between firm fundamentals and financial leverage.

Baral (1996) revealed that profitability, operating cash flow and debt service are positively related to capital structure. Joshi (2008) documented that fixed assets ratio and non-debt tax shield are positively related with leverage whereas growth rate, earning variability, liquidity and profitability are inversely associated with leverage in Nepalese enterprises. Olayinka (2011) argued size, profitability, liquidity and growth are positively related with leverage but tangibility is negatively related with short term leverage. Javed and Imad (2012) identified that total assets, firm size and tangibility are positively related with leverage but growth opportunities have weak relationship with leverage and negative relationship between profitability and leverage.

Numerous theoretical and empirical studies have revealed various factors affect financial and capital structure. These factors can be classified as firm fundamentals and macroeconomic factors. Firm fundamental factors are size, fixed assets, liquidity, earning volatility, growth opportunity, profitability, tangibility etc. Macroeconomic factors are tax policy, 
market interest rates, gross domestic product growth rate, inflation rate, etc. Basically, this paper documents some of firm fundamentals affecting financial structure in Nepalese firms which investigates whether small business firms in under developing economy entertain any unique feature with other developed and developing countries. This paper attempts to analyze firm fundamentals influencing corporate financial leverage of non-financial firms in Nepalese realities. This study is directed to solve issues: (a) what are existing practices of corporate financial leverage in Nepalese non-financial firms?, (b) is there consistency between theory of financial leverage and practice in Nepalese non-financial firms?, (c) what are factors influencing corporate financial leverage in Nepalese firms? and (d) how do firm fundamentals such as size, assets tangibility, age, growth rate, liquidity, profitability and tax shield affect financial leverage in Nepalese non-financial firms?

\section{Objective of the Study}

The basic objective of this paper is to examine the nexus between firm fundamentals and corporate financial leverage of Nepalese non- financial firms.

This paper is structured in to five sections. The first section deals with introduction of financial leverage including issues and objective of this study. Next section two briefly summarizes literature review. Third section covers with research methodology of the paper. Further, section four deals with data results and discussion of this paper. Finally, section five concludes with findings and implication of the study.

\section{Literature review}

Modern theory of corporate financial leverage began with eminent paper of Modigliani and Miller (1958). Several previous theoretical and empirical studies have revealed mixed evidence and findings on factors affecting financial leverage of firms. Numerous studies argued that size can be powerful explanation for cross sectional differences in debt equity ratio. There are two contradictory views on theoretical relationship between size and financial structure of firms. Warner (1977) suggested bankruptcy costs are relatively higher for small firms. Jensen (1986) agreed size has a positive impact on supply of debt. Razan and Zingales (1995) revealed size a proxy for probability of bankruptcy. Thus, it is expected that firms are likely to have higher debt capacity, use more debt to maximize tax benefits. Fama (1985) argued information content of all size firms is not equal due to monitoring costs being relatively higher for small firms. Thus, larger firms due to lower information asymmetry are likely to have easier access to debt market at lower costs. Studies of Harris and Raviv (1990), and Noe (1988) suggest that financial leverage increases value of company. But, Bhat (1980) found insignificant negative relation between size and leverage. This proposition is empirically supported by findings of Ferri and Zones (1979); Kim and Sorensen (1986). In addition, Wald (1999) revealed larger firms have less debt and a small number of professional managers control a sizeable percentage of big industrial firms' stocks and can force management to act in stockholders interest. Finally, result of the study concluded that such centralized company control is responsible for negative coefficient on size. Akinyomi and Olagunju (2013), Danso and Adomako (2014) and Arsov and Naumoski (2016) argued positive nexus between size and capital structure. 
Several theoretical and empirical studies have been made to predict relationship between profitability and financial leverage but not consistent result has been found and there exists theoretical controversy on it. Tax based model suggests profitable firms should borrow more, other things held constant, as they have greater need to shield income from tax. Agency based models give conflicting predictions on relationship between profitability and leverage. Jenson (1986) and Williamson (1988) defined debt as a discipline device to ensure that managers payout profit rather than build empires. For firms with free cash flow and high profitability, high debt can restrain management's discretion. However, Pecking Order Theory of capital structure of Myers (1984) and Myers and Majluf (1984) stated that firm prefers to finance new investment from internal equity and raise debt capital only if retained earnings are not sufficient. Availability of internal capital depends upon profitability of firms. So, it could be expected negative relation between profitability and leverage. Findings of Titman and Wessels (1988), Razan and Zingales (1995), Wald (1999), Booth et al. (2001), Chen and Chen (2011), Arsov and Naumoski (2016) accept this negative relation.

Uses of tangible assets in business firms are expected to be more important in external borrowing at lower cost as it is easy to collateralize them. Titman and Wessels (1988), Rajan and Zingales (1995), Fama and French (2002) argued that tangibility of assets is positively related with leverage. Further, Jenson and Meckling (1976) revealed agency cost of debt exists and if a firm has higher tangible assets can be used as collateral diminishing lender's risk of suffering such agency cost of debt. Similarly, Williamson (1988), Harris and Raviv (1990) suggested leverage should increase with liquidation value. Therefore, leverage should be positively correlated with tangibility. Signaling theory of Myers and Majluf (1984), Akinyomi and Olagunju (2013), Danso and Adomako (2014) also suggested positive relationship between tangibility and financial leverage.

Agency cost theory accepts firms with high growth opportunities should use less debt to mitigate agency problem. Jensen and Meckling (1976) suggested leverage increases with lack of growth opportunities. Titman and Wessels (1988) argued firms with high proportion of noncollaterisable assets could find it more expensive to obtain credit because of assets substitution effect. Stulze and Johnson (1985) show that if management accepts growth objective, then management's and shareholders' interests tend to coincide for firms with strong investment opportunities. Consistent result with this theoretical prediction was supported by study of Rajan and Zingales (1995), Wald (1999), and Booth et al. (2001). Pecking Order Theory (Myers, 1977; Myers \& Majluf, 1984) implies positive relation between leverage and growth rate. The proposition is based on reasoning that faster growing firms are likely to be in need of external fund to finance their positive investment opportunities and prefer debt relative to external equity. This finding is supported by Akinyomi and Olagunju (2013) and Arsove and Naumoski (2016). But, Antoniou et al. (2002) argued strength and role of growth opportunities is likely to vary across countries. If lenders are banks, they represent on board of company and work in close contact with management are fully aware of quality of investment opportunities. This minimized information asymmetry, which in turn affects borrowing ability of firms and risk premium demanded by lenders and vice-versa. 
Firms with high earning volatility carry a risk of earning level below their debt charges, which result acquiring funds at high cost to face risk of bankruptcy. Therefore, firms with high volatile earnings prefer to finance their project through equity. This shows inverse relationship between earning volatility and leverage ratio. Booth et al. (2001), Titman and Wessels (1988), De Angelo and Masulis (1980), Pecking Order theory (1976) accepted business risk is negatively correlated with leverage. However, Hsia (1981) based on contingent claim nature of equity, combines option pricing model, capital assets pricing model and Modigliani and miller theorems to show that as variance of value of firm assets increases, systematic risk of equity decreases. Thus, business risk is positively related with leverage.

There are two contradictory views about impact of liquidity on financial structure of firms. Pecking Order Theory argues that manager prefers internal sources of fund rather than external. Therefore, firms would like to create liquid reserve from retained earnings to finance future investment. Firms with sufficient liquid assets do not need to raise capital from debt. Hence, it is expected to have negative relationship between leverage and liquidity. Ozkan (2001) revealed same result. A firm with higher liquidity ratio raises capital through debt due to having higher debt capacity. This would imply a positive relationship between leverage and liquidity. This finding is supported by result of Awan and Amin (2014).

In general, non-debt tax shield (NDTS) is negatively related with leverage. De Angelo and Masulis (1980) argued NDTS are substitute for tax benefit of debt financing and a firm with larger NDTS is expected to use less debt. Wald (1999) and Chaplinsky and Niehaus (1993), Awan and Amin (2014), Khan et al. (2014) and Arsov and Naumoski (2016) revealed negative relationship between NDTS and leverage. But, Bradley et al. (1984) argued inverse result.

The prior studies have reported different relationship between firm's age and financial leverage. Bhaduri (2002) proposed that young firms are more vulnerable to problem of asymmetric information, and they are likely to use debt and avoid equity market. Hence, it is reported negative relationship between firm's age and financial leverage. Pittman (2002) revealed younger firms at an earlier stage in their developments rely more on investment tax shields and less on debt tax shields. Ezeoha (2008) argued positive and significant relationship between firm's age and financial leverage that older firms more likely to have accumulated internal finances, and less likely borrowed fund.

\section{Research methodology \\ Research design}

This paper has used descriptive and causal-comparative research designs to deal with nexus between firm fundamentals and financial leverage in Nepalese non-financial firms. Descriptive research design has been applied to explain factors influence financial leverage. Causal-comparative research design is used to examine nexus between explanatory variables and financial leverage. Pearson's correlation coefficient is employed to analyze variables relationship. Ordinary least square regression models have been used to examine cause and effect of firm fundamental on financial leverage. 


\section{Nature and sources of data}

This study is made based on secondary sources of data. Secondary sources of data have been used for examination of annex between firm fundamentals and financial leverage of Nepalese non-financial firms. Data have been collected from Security Board of Nepal (SEBON) and annual reports of sample firms. Financial data of each sample firm for 18 fiscal years covering fiscal year2000/01 to 2017/18 have been collected.

\section{Population and sample}

In this paper, all listed non-financial firms in Nepal Stock Exchange Ltd. (NEPSE) are considered as population. These firms represent manufacturing and processing, trading, hotels and hydropower sectors etc. Total 49 non-financial firms (manufacturing and processing 18, trading 4, hotel 4, hydropower 19 and other 4) listed in NEPSE by the end of fiscal year 2017/18. Out of these listed firms, 12 firms have been selected as sample firms. In this paper, 18 observations from each of sample firm and total 216 observations are used to analyze nexus between firm fundamentals and financial leverage. Financial institutions such as banks, finance companies, insurance companies etc. are excluded from sample. This exclusion is due to fact that nature and characteristics of such firms differs significantly with non-financial firms and debt of these firms like liabilities are not strictly comparable to debt issued by non-financial firms (Rajan \& Zingales, 1995).

\section{Analytical tools}

In this paper, data processing and analysis have been made using SPSS (version 20) and MSExcel program. This study has employed descriptive statistics to analyze average, minimum, maximum values and standard deviations of various variables. Pearson's correlation analysis has been used to analyze association among dependent and explanatory variables. Both univariate and multivariate regression models have been applied to examine effects of explanatory variables on financial leverage of firms. This paper has used t-test, F-test, adjusted coefficient of determination $\left(\mathrm{Adj}, \mathrm{R}^{2}\right)$ to analyze data to examine nexus between firm fundamentals and financial leverage of Nepalese non-financial firms.

\section{Variables}

In this paper, short-term financial leverage (short-term debt to total assets), long-term financial leverage (long-term debt to total assets) and total financial leverage (total debt to total assets) ratios are proxy variables to measure financial leverage used as dependent variables. In this paper, size of firm, profitability, tangibility, growth rate, earning variability, liquidity, non debt tax shield, and age of firms are considered as independent variables.

Size: Size of firm is one of determinants of financial structure. Prior empirical studies revealed size has positive impact on financial leverage of firms (Warner, 1977; Jenson, 1986; Razan \& Zingales, 1995; Harris \& Raviv, 1990), but Bhat (1980) argued insignificant negative relation between size and leverage which is empirically supported by findings of Ferri and Zones (1979), Kim and Sorensen (1986). In this paper, size is used as natural logarithm of total sales of firms and is expected to be positively associated with leverage. 
Profitability: Prior theoretical and empirical studies argued theoretical controversy on profitability. Tax based model suggests profitable firms are positively related with financial leverage. Agency based models give conflicting predictions on relationship between profitability and leverage. Jenson (1986) and Williamson (1988) argued leverage and profitability are positively related. However, Pecking Order Theory (Myers \& Majluf; 1984) revealed that firm prefers to finance new investment from internal equity, and debt capital is used only if retained earnings are insufficient. Hence, it is expected negative relation between profitability and leverage. Findings of Titman and Wessels (1988), Razan and Zingales (1995), and Booth et al. (2001) support to the result of Myers and Majluf (1984). In this paper, profitability is used as operating profit ratio.

Tangibility: Tangible assets act as collateral and provide security to lenders in events of financial distress. Presence of tangible assets is expected to be more important in external borrowings at lower cost as it is easy to collateralize. Myers and Majluf (1984), Titman and Wessels (1988), Rajan and Zingales (1995) argued tangibility of assets is positively related with financial leverage. In this paper, tangibility is ratio of fixed assets to total assets.

Growth rate: In one hand, theoretical studies suggest growth opportunities are negatively related with leverage (Jensen \& Meckling, 1976; Titman \& Wessels, 1988; Stulz, 1985) and this theoretical prediction was supported by studies of Rajan and Zingales (1995) and Booth et al. (2001). On other hand, Pecking Order Theory (Myers, 1977; Myers \& Majluf, 1984) argued positive relation between leverage and growth rate. But, Antoniou (2002) argued strength and role of growth opportunities is likely to vary across countries. In this paper, growth rate is defined as growth rate of total assets of firms and used as explanatory variable.

Earning variability: Firms with high earning variability carry a risk of earnings and earning level of firm will be below the level of debt charges. Firm which acquire funds at high cost face risk of bankruptcy. Therefore, firms with high volatile earnings prefer to finance their project through equity. This shows an inverse relation between earning variability and leverage ratio (Booth et al., 2001; Bradley et al., 1984; Titman \& Wessels, 1988; Pecking Order theory, 1976). However, Hsia (1981) argued positive relationship between earning variability and leverage of firms. In this paper, earning variability is used as coefficient of variation of operating profit of firms.

Liquidity: There are two contradictory views about impact of liquidity on financial structure of firms. On one hand, Pecking Order Theory argues to use internal sources of fund to create liquid reserve from retained earnings than to use debt capital and is expected to have negative relationship between leverage and liquidity. On other hand, firm with higher liquidity ratio has higher debt servicing capacity and capital can be managed through debt which implies a positive relationship between liquidity and leverage. In this paper, liquidity is current ratio which is determined as current assets to current liabilities of firms. 
Non debt tax shield: Tax deduction for depreciation and investment tax credit is called non-debt tax shield (NDTS). In general, it is accepted that NDTS is negatively related with leverage. De Angelo and Masulis (1980) argued NDTS are substitute for tax-benefit of debt financing and a firm with larger NDTS is expected to use less debt which supported by Wald (1999) and Chaplinsky and Niehaus (1993), but Bradley at el. (1984) found opposite result. In this paper, NDTS is computed as ratio of depreciation to total assets.

Age: Prior empirical studies have revealed different relationship between firm's age and financial leverage. Young firms are more vulnerable to the problem of asymmetric information, and hence they are likely to use debt and avoid equity market (Bhaduri, 2002). Hence, there is negative relationship between firm's age and financial leverage. Ezeoha (2008) revealed positive and significant relationship between firm's age and financial leverage which implies that a older firm like to use more debt and less equity financing and vice-versa. In this study, age has been used as the proxy of age of firms.

\section{Model specification}

Multiple regression models of Equation (1), (2) and (3) are used to analyze impact of explanatory variables on financial leverage of Nepalese non-financial firms.

$$
\begin{aligned}
& \text { TFL }=\beta_{0}+\beta_{1} S I Z E+\beta_{2} P R O+\beta_{3} T A N+\beta_{4} G R O+\beta_{5} E V+\beta_{6} L I Q+\beta_{7} N D T S+\beta_{8} A G E+\mu \ldots \\
& S F L=\beta_{0}+\beta_{1} S I Z E+\beta_{2} P R O+\beta_{3} T A N+\beta_{4} G R O+\beta_{5} E V+\beta_{6} L I Q+\beta_{7} N D T S+\beta_{8} A G E+\mu \ldots \\
& L F L=\beta_{0}+\beta_{1} S I Z E+\beta_{2} P R O+\beta_{3} T A N+\beta_{4} G R O+\beta_{5} E V+\beta_{6} L I Q+\beta_{7} N D T S+\beta_{8} A G E+\mu \ldots
\end{aligned}
$$

TFL is total financial leverage, SFL represents short-term financial leverage, SFL indicates long-term financial leverage, SIZE refers natural logarithm of total sale, PRO is profitability ratio, TAN represents tangibility, GRO indicates growth rate, EV is earning variability, LIQ represents liquidity ratio, NDTS refers non debt tax shield ratio, AGE is age of firms, $\beta_{0}$ is coefficient of consonant or intercept term, $\beta_{1}, \beta_{2} \ldots, \beta_{8}$ are coefficients of explanatory variables, and $\mu$ is error term.

\section{Results and discussion Descriptive statistics}

Table 1 shows descriptive statistics of variables used in this paper. Panel A depicts mean, standard deviations, minimums and maximums values of variables of individual industries whereas Panel B presents descriptive statistics of all sample firms of the study. 
Table 1

Descriptive statistics of variables

\begin{tabular}{|c|c|c|c|c|c|c|c|c|c|c|c|c|c|c|c|}
\hline \multicolumn{16}{|c|}{ Panel: A } \\
\hline \multirow[t]{2}{*}{ Variables } & \multicolumn{5}{|c|}{$\begin{array}{l}\text { Trading, Manufacturing \& Process } \\
\text { Companies }\end{array}$} & \multicolumn{5}{|c|}{ Hotels Companies } & \multicolumn{5}{|c|}{ Hydropower Companies } \\
\hline & No. & Mean & Std. Dev. & Min & Max. & No. & Mean & Std. Dev. & Min. & Max. & No. & Mean & Std. Dev. & Min & Max \\
\hline SFL & 108 & 0.634 & 0.193 & 0.145 & 0.931 & 36 & 0.338 & 0.161 & 0.081 & 0.665 & 72 & 0.224 & 0.135 & 0.021 & 0.425 \\
\hline LFL & 108 & 0.087 & 0.136 & 0.000 & 0.462 & 36 & 0.473 & 0.272 & 0.000 & 0.864 & 72 & 0.191 & 0.253 & 0.000 & 0.663 \\
\hline TFL & 108 & 0.696 & 0.194 & 0.154 & 0.943 & 36 & 0.764 & 0.164 & 0.432 & 0.963 & 72 & 0.414 & 0.182 & 0.182 & 0.734 \\
\hline SIZE & 108 & 16.792 & 1.415 & 10.906 & 22.306 & 36 & 14.085 & 0.491 & 11.953 & 16.051 & 72 & 14.622 & 1.091 & 11.013 & 13.782 \\
\hline PRO & 108 & 0.313 & 0.307 & 0.035 & 1.147 & 36 & 0.137 & 0.083 & -0.041 & 0.256 & 72 & 0.227 & 0.064 & 0.092 & 0.291 \\
\hline TAN & 108 & 0.374 & 0.254 & 0.037 & 0.784 & 36 & 0.854 & 0.135 & 0.564 & 0.973 & 72 & 0.754 & 0.193 & 0.415 & 0.964 \\
\hline GRO & 108 & 0.165 & 0.318 & -0.443 & 1.273 & 36 & 0.182 & 0.236 & -0.491 & 0.747 & 72 & 0.063 & 0.092 & -0.156 & 0.206 \\
\hline EV & 108 & 0.216 & 0.093 & 0.136 & 0.462 & 36 & 0.091 & 0.082 & 0.113 & 0.474 & 72 & 0.216 & 0.083 & 0.183 & 0.473 \\
\hline LIQ & 108 & 1.343 & 0.892 & 0.345 & 5.715 & 36 & 0.973 & 0.917 & 0.092 & 4.375 & 72 & 1.455 & 0.816 & 0.227 & 3.591 \\
\hline NDTS & 108 & 0.128 & 0.106 & 0.000 & 0.302 & 36 & 0.055 & 0.025 & 0.035 & 0.083 & 72 & 0.064 & 0.033 & 0.025 & 0.117 \\
\hline AGE & 108 & 2.972 & 0.635 & 0.392 & 2.851 & 36 & 2.982 & 0.564 & 1.957 & 3.664 & 72 & 2.592 & 0.304 & 1.956 & 3.045 \\
\hline \multicolumn{16}{|c|}{ Panel: B } \\
\hline \multirow{2}{*}{\multicolumn{2}{|c|}{ Variables }} & & \multicolumn{13}{|c|}{ All Samples Companies. } \\
\hline & & \multicolumn{4}{|c|}{ No. } & \multicolumn{2}{|l|}{ Mean } & \multicolumn{3}{|c|}{ Std. Dev. } & \multicolumn{3}{|c|}{ Min } & \multicolumn{2}{|l|}{ Max } \\
\hline \multicolumn{2}{|c|}{ SFL } & \multicolumn{3}{|c|}{216} & \multicolumn{3}{|c|}{0.445} & \multicolumn{3}{|c|}{0.272} & \multicolumn{3}{|c|}{0.021} & \multicolumn{2}{|l|}{0.931} \\
\hline \multicolumn{2}{|c|}{ LFL } & \multicolumn{3}{|c|}{216} & \multicolumn{3}{|c|}{0.224} & \multicolumn{3}{|c|}{0.291} & \multicolumn{3}{|c|}{0.000} & \multicolumn{2}{|l|}{0.864} \\
\hline \multicolumn{2}{|c|}{ TFL } & \multicolumn{3}{|c|}{216} & & 0.643 & & & 0.226 & & & 0.154 & & 0.963 & \\
\hline & $\mathrm{ZE}$ & & 216 & & & 16.185 & & & 1.153 & & & 10.906 & & 22.306 & \\
\hline & $\mathrm{RO}$ & & 216 & & & 0.226 & & & 0.245 & & & -0.041 & & 1.146 & \\
\hline & AN & & 216 & & & 0.627 & & & 0.307 & & & 0.037 & & 0.973 & \\
\hline & $\mathrm{RO}$ & & 216 & & & 0.134 & & & 0.254 & & & -0.443 & & 1.273 & \\
\hline & $\mathrm{V}$ & & 216 & & & 0.127 & & & 0.093 & & & 0.113 & & 0.474 & \\
\hline & [Q & & 216 & & & 1.156 & & & 0.905 & & & 0.092 & & 5.715 & \\
\hline & TS & & 216 & & & 0.063 & & & 0.072 & & & 0.000 & & 0.302 & \\
\hline & GE & & 216 & & & 2.891 & & & 0.581 & & & 0.392 & & 3.045 & \\
\hline
\end{tabular}

Source: SEBON (2000/01-2017/18)

Panel A depicts hotel industry have the highest total financial leverage during study period with mean value of 0.764 . Evidence shows companies are using higher debt to finance their assets. The smallest average total leverage is in hydropower companies with value of 0.414 indicating less use of debt finance for assets. Panel B depicts average short-term leverage for whole sample is 0.445 indicating 44.5 percent assets of firms are financed by short-term debt. This result highlights importance on short-term debt over long-term debt in Nepalese firms. Short-term financial leverage is found highest in trading and manufacturing companies (0.634) and lowest (0.224) in hydropower companies. Average long-term financial leverage is observed to be highest in hotel industries (0.473), which is higher than whole sample mean (0.224). Standard deviations in Panel B show the highest variation in use of long-term financial leverage and less variation in use of total leverage. Minimum use of total financial leverage of Nepalese firms is 0.154 and maximum is 0.963 . 
In terms of size, trading and manufacturing companies have the largest mean size of 16.792 as natural logarithm of sales, followed by hotels with mean of 14.085. While mean size of all sample firms is 16.185 , hydropower companies seem to be the smallest companies with mean value of 14.622.Average profitability ratio of all sample firms is 22.6 percent with maximum and minimum value of -4.1 and 114.6 percent. Trading and manufacturing companies have the highest profitability with mean, standard deviation, minimum and maximum value of 31.3 percent, 30.7 percent, 3.5 percent and 114.7 percent respectively. Hotels are observed to be least profitable among all industries with mean vale of profitability of 13.7 percent.

Average asset tangibility ratio of all firms is 0.627 with standard deviation of 0.307 and minimum and maximum value of 0.037 and 0.973 , indicating sample companies are quite different in terms of capital intensity. In terms of asset tangibility, hotels are found more capital intensive with mean value of 0.854 and trading and manufacturing industries are the least capital intensive with mean value of 0.374 . While average tangibility ratio of all firms is observed 0.627, differences are noticed among firms in terms of their investment in fixed assets. Average growth rate of all companies during study period has been found 13.4 percent with standard deviation of 0.254 and minimum and maximum value of -0.443 and 1.273. Average growth rate of trading and manufacturing companies and hotels are 0.165 and 0.182 whereas hydropower companies have the lowest growth rate ofsales. Average growth rate of hydropower companies is observed 6.3 percent with standard deviation of 0.092 and minimum and maximum value of -15.6 percent and 20.6 percent.

Average earning variability of all firms is 0.127 with standard deviation, minimum and maximum value of $0.093,0.113$ and 0.474 respectively. Hotels have lowest earning variability whereas trading and manufacturing and hydropower companies have higher variability. Average liquidity ratio of all firms is 1.156 times with standard deviation, minimum and maximum value of $0.905,0.092$ and 5.715. The highest ratio is observed for hydropower companies with average liquidity ratio 1.455 and hotel industry seems the least liquid with average liquidity ratio 0.973. Average liquidity ratios of all firms are lower than standard current ratio of 2 times. Average non-debt tax shield ratio in all firms is 0.063 times with standard deviation of 0.072 and minimum and maximum value of 0 and 0.302 respectively. The highest average non-debt tax shield (0.128) is in case of trading and manufacturing companies and lowest ratio (0.055) is found in hotels. Firms are found different in term of their maturity. Result reveals that hotels are the most matured and hydropower companies are least matured. 


\section{Correlation analysis}

Table 2 shows Pearson's correlation coefficient of variables to explain the nexus between firm fundamentals (explanatory variables) and financial leverage of Nepalese non-financial firms.

\section{Table 2}

Correlation coefficients among the variables

\begin{tabular}{cccccccccccc}
\hline Variables & SFL & LFL & TFL & SIZE & PRO & TAN & GRO & EV & LIQ & NDTS & AGE \\
\hline SFL & 1 & $-0.417^{* *}$ & $0.476^{* *}$ & 0.246 & $-0.262^{* *}$ & $-0.260^{* *}$ & $0.314^{* *}$ & $0.425^{*}$ & $-0.360^{* *}$ & -0.171 & 0.382 \\
LFL & - & 1 & $0.424^{* *}$ & $0.363^{* *}$ & $-0.431^{* *}$ & $0.398^{* *}$ & 0.292 & $0.285^{*}$ & $-0.374^{*}$ & -0.122 & 0.370 \\
TFL & - & - & 1 & 0.413 & $-0.194^{*}$ & $0.482^{*}$ & 0.220 & $0.338^{*}$ & $-0.482^{* *}$ & -0.057 & 0.297 \\
SIZE & - & - & - & 1 & 0.157 & $-0.396^{* *}$ & 0.086 & 0.133 & 0.014 & $0.236^{*}$ & $0.213^{*}$ \\
PRO & - & - & - & - & 1 & $-0.365^{* *}$ & -0.147 & $-0.448^{*}$ & 0.077 & $0.420^{* *}$ & 0.025 \\
TAN & - & - & - & - & - & 1 & -0.096 & $-0.143^{* *}$ & $-0.322^{* *}$ & -0.188 & $-0.340^{* *}$ \\
GRO & - & - & - & - & - & - & 1 & 0.085 & -0.050 & -0.033 & -0.110 \\
EV & - & - & - & - & - & - & - & 1 & -0.120 & $0.244^{*}$ & $0.265^{*}$ \\
LIQ & - & - & - & - & - & - & - & - & 1 & -0.075 & -0.014 \\
NDTS & - & - & - & - & - & - & - & - & - & 1 & $-0.204^{*}$ \\
AGE & - & - & & - & - & - & - & - & - & - & 1 \\
\hline
\end{tabular}

Source: SEBON (2000/01-2017/18)

Note: $\quad{ }^{*}$ Correlation is significant at $1 \%$ level \& $*$ Correlation is significant at $5 \%$ levels (2-tailed)

Table 2 shows firm's size is positively correlated with all measures of leverage. However, correlation is statistically significant at 1 percent level only with long-term financial leverage. It indicates size has no strong association with short-term and total financial leverage in Nepalese firms. Negative and significant relationship has been found between profitability and all measures of financial leverage which indicates profitable Nepalese firms tend to use less debt. Tangibility is negatively correlated with short-term financial leverage at 1 percent level but positively correlated with long-term and total leverage which implies that firms having higher tangible assets use less short-term financial leverage in Nepalese non-financial firms.

Although growth opportunity is positively correlated with all measures of leverage, correlation is statistically significant only with short-term leverage which indicates growth opportunity has no significant effect on use of long-term and total debt. Earning variability is positively related with all financial leverage and has significant effect on use of all sources of financing. Association between corporate liquidity and all measures of financial leverage is negative and statistically significant. Result indicates firms having higher liquidity tends to use lower debt.

Nexus between non-debt tax shield and all measures of financial leverage is negative but not statistically significant, indicating non-debt tax shield cannot be expected as determinant of corporate financial leverage in Nepalese firm. Although age is positively correlated with all measures of leverage, relationship is not significant. This result indicates firm's age is not expected as major determinant of corporate financial leverage in Nepal. Insignificant nexus between age and financial leverage is not in line with priori hypothesis. Correlation coefficients among 
explanatory variables are less than 0.5 which implies they are not highly correlated. Therefore, multicolinearity may not be serious problem while estimating parameters.

\section{Regression analysis}

In this paper, various regression models have been used to examine the nexus between financial leverage and explanatory variables of non-financial firms. Regression results of short-term financial leverage with its explanatory variables are presented in Table 3.

\section{Table 3}

Nexus of short-term financial leverage with firm-fundamental variables

\begin{tabular}{|c|c|c|c|c|c|c|c|c|c|c|c|}
\hline Model & Constant & SIZE & PRO & TAN & GRO & EV & LIQ & NDTS & AGE & Adj. $R^{2}$ & $\mathrm{~F}$ \\
\hline 1 & $\begin{array}{c}0.123^{*} \\
(0.136)\end{array}$ & $\begin{array}{c}0.035 \\
(0.124)\end{array}$ & - & - & - & - & - & - & - & 0.182 & $23.45^{* *}$ \\
\hline 2 & $\begin{array}{c}-0.663 \\
(-0.714)\end{array}$ & - & $\begin{array}{c}-0.242^{* *} \\
(0.346)\end{array}$ & - & - & - & - & - & - & 0.335 & $25.61^{* *}$ \\
\hline 3 & $\begin{array}{c}-0.167^{\star *} \\
(-0.261)\end{array}$ & - & - & $\begin{array}{l}-0.164^{*} \\
(-0.215)\end{array}$ & - & - & - & - & - & 0.257 & $32.54^{* *}$ \\
\hline 4 & $\begin{array}{l}0.159^{*} \\
(0.246)\end{array}$ & - & - & - & $\begin{array}{l}0.128^{* *} \\
(0.245)\end{array}$ & - & - & - & - & 0.291 & $35.38^{* *}$ \\
\hline 5 & $\begin{array}{c}0.285 \\
(0.291)\end{array}$ & - & - & - & - & $\begin{array}{c}0.415 \\
(0.427)\end{array}$ & - & - & - & 0.273 & $15.29^{* *}$ \\
\hline 6 & $\begin{array}{l}-1.278^{*} \\
(-1.471)\end{array}$ & - & - & - & - & - & $\begin{array}{l}-1.524^{*} \\
(-1.643)\end{array}$ & - & - & 0.254 & $18.56^{* *}$ \\
\hline 7 & $\begin{array}{c}-2.384^{* *} \\
(-2.531)\end{array}$ & - & - & - & - & - & - & $\begin{array}{c}-2.256 \\
(-2.175)\end{array}$ & - & 0.258 & $21.48^{* *}$ \\
\hline 8 & $\begin{array}{c}0.783 \\
(0.825)\end{array}$ & - & - & - & - & - & - & - & $\begin{array}{c}0.682 \\
(0.755)\end{array}$ & 0.217 & $24.36^{* *}$ \\
\hline 9 & $\begin{array}{c}1.628 \\
(1.851)\end{array}$ & $\begin{array}{c}0.036 \\
(0.164)\end{array}$ & - & $\begin{array}{l}-0.146^{*} \\
(-0.205)\end{array}$ & $\begin{array}{l}0.153^{* *} \\
(0.215)\end{array}$ & - & - & $\begin{array}{c}-2.167 \\
(-2.743)\end{array}$ & $\begin{array}{c}0.628 \\
(0.747)\end{array}$ & 0.325 & $26.29^{* *}$ \\
\hline 10 & $\begin{array}{l}-1.675 \\
(-.089)\end{array}$ & - & $\begin{array}{c}-0.237^{* *} \\
(-0.416)\end{array}$ & $\begin{array}{l}-0.126^{*} \\
(-0.425)\end{array}$ & $\begin{array}{l}0.291^{* *} \\
(0.375)\end{array}$ & - & $\begin{array}{c}-0.156^{* *} \\
(-0.346)\end{array}$ & - & - & 0.362 & $33.57^{* *}$ \\
\hline 11 & $\begin{array}{l}0.685^{* *} \\
(0.732)\end{array}$ & $\begin{array}{c}0.074 \\
(0.136)\end{array}$ & $\begin{array}{c}-0.203^{* *} \\
(-0.371)\end{array}$ & $\begin{array}{c}-0.119^{* *} \\
(-0352)\end{array}$ & $\begin{array}{l}0.127^{*} \\
(0.324)\end{array}$ & $\begin{array}{l}0.627^{* *} \\
(0.803)\end{array}$ & $\begin{array}{l}-0.139 * * \\
(-0.251)\end{array}$ & $\begin{array}{c}-0.178 \\
(-0.235)\end{array}$ & $\begin{array}{c}0.061 \\
(0.183)\end{array}$ & 0.415 & $39.68^{* *}$ \\
\hline
\end{tabular}

Source: SEBON (2000/01-2017/18)

Note: **and * indicate significant at 1 percent and 5 percent level significance. This table presents results of regression models designed to analyze the impact of eight firm fundamental variables on short-tem financial leverage. Table also presents value of F-statistic and Adjusted R-square of each model. The values in parenthesis are t-statistics.

Table 3 shows positive effect of size of firm on short-term financial leverage. Although sign of coefficient is as per priori expectation, it is not statistically significant in all models. This result indicates use of short-term debt is not affected by company's size in Nepalese nonfinancial firms. This result contradicts with findings of Booth et al. (2001), Rajan and Zingales (1995) and Wald (1999). Profitability has negative signs in all models for short-term financial leverage. All regression coefficients are as per expectation and statistically significant which indicate profitable firms use less short-term financial leverage. The negative relationship 
between leverage and profitability is consistent with findings of Rajan and Zingales (1995), and Booth et al. (2001).

Coefficients of tangibility are negative and significant in all regression models. Negative relationship between tangibility and leverage has not been supported priori hypothesis. This result indicates companies with more tangible assets use less short-term borrowing. Coefficient of growth opportunity is 0.128 in model 4 and $0.153,0.291$ and 0.127 in three multivariate models 9, 10 and11 respectively. This result indicates growing firms use more short-term debt. This finding is consistent with results of Dawns (1994) but contradicts with finding of Rajan and Zingales (1995).

Table 3 shows positive relation between earning variability and short-term leverage. Regression result shows earning variability has significant impact on short-term leverage of Nepalese non-financial firms at 1 percent level. Coefficients of liquidity are negative in all models and statistically significant as per priori hypothesis. It reveals that companies with high liquidity tend to avoid higher short-term debt. This negative and significant relationship between liquidity and leverage is consistent with findings of Jordon et al. (1998), Ozkan (2001), and Antoniou et al.(2002).

The coefficient of non-debt tax shield is negative in all models but not statistically significant. This result indicates that non-debt tax shield is irrelevant in use of short-term debt by Nepalese firms. This finding contradicts with findings of DeAngelo and Masulis (1980), Titman and Wessels (1988), and Jensen et al. (1992) which have reported negative and significant relationship between non-debt tax shield and corporate financial leverage. AGE has a positive sign but coefficients are not statistically significant in all models. This result indicates age does not significantly affect amount of short-term debt used in financial structure in Nepalese non-financial firms. This result contradicts with finding of Bhaduri (2002).Adjusted coefficient of determinants (Adj. $R^{2}$ ) shows predicting power of regression models to analyze explanatory power of firm fundamentals on short-term financial leverage. Adj. $R^{2}$ of model 11 with inclusion of all explanatory variables is 0.415 which indicates predicting power of regression model is 41.5 percent to explain short-term financial leverage by its explanatory variables. F-statistics of all regression models are statistically significant at 1 percent level which implies the fitness of test of overall models. The nexus of long-term financial leverage with its explanatory variables are presented in Table 4. 
Table 4

Nexus of long-term financial leverage with firm-fundamental variables

\begin{tabular}{|c|c|c|c|c|c|c|c|c|c|c|c|}
\hline Model & Constant & SIZE & PRO & TAN & GRO & EV & LIQ & NDTS & AGE & Adj.R ${ }^{2}$ & $\mathrm{~F}$ \\
\hline 1 & $\begin{array}{c}0.089^{*} \\
(0.135)\end{array}$ & $\begin{array}{l}0.058^{* *} \\
(0.0682)\end{array}$ & - & - & - & - & - & - & - & 0.281 & $21.351 * *$ \\
\hline 2 & $\begin{array}{c}-1.309 \\
(-1.125)\end{array}$ & - & $\begin{array}{c}-0.271 * * \\
(-0.301)\end{array}$ & - & - & - & - & - & - & 0.284 & $25.625^{* *}$ \\
\hline 3 & $\begin{array}{l}1.242^{* *} \\
(1.438)\end{array}$ & - & - & $\begin{array}{l}0.283^{*} \\
(0.391)\end{array}$ & - & - & - & - & - & 0.237 & $23.231 * *$ \\
\hline 4 & $\begin{array}{l}0.531^{*} \\
(0.691)\end{array}$ & - & - & - & $\begin{array}{c}0.415 \\
(0.513)\end{array}$ & - & - & - & - & 0.272 & $21.306^{* *}$ \\
\hline 5 & $\begin{array}{c}0.286 \\
(0.371)\end{array}$ & - & - & - & - & $\begin{array}{c}0.382 \\
(0.416)\end{array}$ & - & - & - & 0.229 & $16.237 * *$ \\
\hline 6 & $\begin{array}{l}-0.143^{*} \\
(-0.205)\end{array}$ & - & - & - & - & - & $\begin{array}{c}-0.194 * * \\
(-0.205)\end{array}$ & - & - & 0.242 & $25.381 * *$ \\
\hline 7 & $\begin{array}{l}1.351^{* *} \\
(1.834)\end{array}$ & - & - & - & - & - & - & $\begin{array}{c}-0.267 \\
(-0.251)\end{array}$ & - & 0.124 & $23.427 * *$ \\
\hline 8 & $\begin{array}{l}0.652^{*} \\
(0.675)\end{array}$ & - & - & - & - & - & - & - & $\begin{array}{l}0.154^{*} \\
(0.243)\end{array}$ & 0.235 & $24.311^{* *}$ \\
\hline 9 & $\begin{array}{l}-0.128^{*} \\
(0.305)\end{array}$ & $\begin{array}{c}0.141^{* *} \\
(0.150)\end{array}$ & - & $\begin{array}{l}0.165^{*} \\
(0.192)\end{array}$ & $\begin{array}{c}0.107 \\
(0.153)\end{array}$ & - & - & $\begin{array}{c}-0.275 \\
(-0.284)\end{array}$ & $\begin{array}{c}0.154 \\
(0.280)\end{array}$ & 0.302 & $25.847 * *$ \\
\hline 10 & $\begin{array}{l}1.607^{* *} \\
(1.971)\end{array}$ & - & $\begin{array}{c}-0.204 * * \\
(-0.328)\end{array}$ & $\begin{array}{l}0.157^{*} \\
(0.241)\end{array}$ & $\begin{array}{c}0.134 \\
(0.175)\end{array}$ & - & $\begin{array}{c}-0.138^{* *} \\
(-0.206)\end{array}$ & - & - & 0.316 & $28.615^{* *}$ \\
\hline 11 & $\begin{array}{l}0.417 * \\
(0.538) \\
\end{array}$ & $\begin{array}{l}0.095^{*} \\
(0.103) \\
\end{array}$ & $\begin{array}{l}-0.199 * \\
(-0.304) \\
\end{array}$ & $\begin{array}{l}0.156^{*} \\
(0.246) \\
\end{array}$ & $\begin{array}{c}0.124 \\
(0.157) \\
\end{array}$ & $\begin{array}{l}0.627^{*} \\
(0.715)\end{array}$ & $\begin{array}{r}-0.129 * * \\
(-0.273) \\
\end{array}$ & $\begin{array}{c}-0.209 \\
(-0.286) \\
\end{array}$ & $\begin{array}{c}0.160 \\
(0.182) \\
\end{array}$ & 0.327 & $28.421^{* *}$ \\
\hline
\end{tabular}

Source: SEBON (2000/01-2017/18)

Note: **and * indicate significant at 1 percent and 5 percent level of significance. This table presents results of regression model designed to analyze the impact of eight firm fundamental variables on longtem financial leverage. Table also presents the value of F-statistic and Adjusted R-square of each model. The values in parenthesis are $\mathrm{t}$-statistics.

Table 4 exhibits positive effect of firm's size on long-term financial leverage. Regression coefficients are positive 0.058 in model 1 and 0.141 and 0.095 in multivariate models 9 and 11 respectively. Coefficients have been found significant in all models as per priori hypothesis. This result indicates use of long-term debt is statistically significantly affected by firms' size in Nepalese non-financial firms. Profitability has negative signs in all models for long-term financial leverage. Results are as per expected sign and coefficients are statistically significant which indicates profitable firms use less long-term financial leverage/debt. The negative relationship between long-term leverage and profitability is consistent with pecking order theory and findings of Rajan and Zingales (1995), and Booth et al. (2001).

As reported in Table 4, coefficients of tangibility are positive and are statistically significant in all univariate and multivariate models. This result indicates firms with more tangible assets use more log-term debt. It supports to the finding of Titman and Wessels (1988), Jensen (1992), Rajan and Zingels (1995), Booth et al. (2001).Coefficient of growth opportunity is 0.415 
in univariate model and $0.107,0.134$ and 0.124 in three multivariate models. Although sign of coefficients are as expected, but are not statistically significant in all models. This result indicates that growth opportunity is irrelevant in use of long-term debt by Nepalese nonfinancial firms. This finding supports with findings of Myers and Majluf (1984) and contradicts with results of Chaplinsky and Niehaus (1993), Rajan and Zingales (1995) who had reported negative relationship between growth opportunity and leverage.

Regression results of model 5 and model 11 show a positive relationship between long-term financial leverage and earning variability. Regression result of multivariate models indicate that earning variability has significant impact on long-term financial leverage at 5 percent level. The coefficients of liquidity are negative and statistically significant in both univaraite and multivariate models. Further, all coefficients are as per priori hypothesis which indicates companies with high liquidity tend to avoid higher long-term debt. The observed findings are consistent with results of Jordon et al. (1998), Ozkan (2001), and Antoniou et al. (2002).

Results show negative sign of non-debt tax shield in all models but coefficients are not statistically significant. This result indicates use of long-term debt is not affected by non-debt tax shield in Nepalese non-financial firms. This finding contradicts with results of DeAngelo and Masulis (1980), Titman and Wessels (1988), and Jensen et al. (1992), which have reported negative and significant relationship between non-debt tax shield and corporate financial leverage. AGE has a positive sign but coefficients are not statistically significant both in univariate and multivariate models. Result indicates age of firm does not significantly affect amount of long-term debt used in financial structure of Nepalese firms. This result is not consistent with findings of Bhaduri (2002)who has reported positive relationship between age and long-term financial leverage of firms.

Adj. $R^{2}$ of model 11 with inclusion of all explanatory variables is 0.327 which indicates predicting power of regression models is 32.7 percent to explain long-term financial leverage of Nepalese firms by its explanatory variables. F-statistics of all regression models are statistically significant at 1 percent level which implies the fitness of test of overall models. Table 5 presents results of regression models designed to analyze nexus between firmfundamentals and total financial leverage of Nepalese non-financial firms. 
Table 5

Nexus of total financial leverage with firm-fundamental variables

\begin{tabular}{|c|c|c|c|c|c|c|c|c|c|c|c|}
\hline Model & Constant & SIZE & $\overline{\mathrm{PRO}}$ & $\overline{\text { TAN }}$ & GRO & $\overline{\mathrm{EV}}$ & LIQ & NDTS & $\overline{\text { AGE }}$ & Adj. $R^{2}$ & $\bar{F}$ \\
\hline 1 & $\begin{array}{l}0.075^{*} \\
(0.039)\end{array}$ & $\begin{array}{c}0.059 \\
(0.168)\end{array}$ & - & - & - & - & - & - & - & 0.218 & $14.561^{* *}$ \\
\hline 2 & $\begin{array}{c}-0.875 \\
(-1.168)\end{array}$ & - & $\begin{array}{c}-0.279 * * \\
(-0.306)\end{array}$ & - & - & - & - & - & - & 0.326 & $24.751 * *$ \\
\hline 3 & $\begin{array}{l}1.519 * * \\
(1.806)\end{array}$ & - & - & $\begin{array}{l}0.976^{*} \\
(1.291)\end{array}$ & - & - & - & - & - & 0.347 & $29.285^{* *}$ \\
\hline 4 & $\begin{array}{c}0.575 \\
(0.723)\end{array}$ & - & - & - & $\begin{array}{c}0.396 \\
(0.418)\end{array}$ & - & - & - & - & 0.239 & $34.352^{* *}$ \\
\hline 5 & $\begin{array}{c}0.287 \\
(0.315)\end{array}$ & - & - & - & - & $\begin{array}{l}0.355^{*} \\
(0.604)\end{array}$ & - & - & - & 0.247 & $15.226^{* *}$ \\
\hline 6 & $\begin{array}{c}-0.178 \\
(-0.197)\end{array}$ & - & - & - & - & - & $\begin{array}{c}-0.172 * * \\
(-0.463)\end{array}$ & - & - & 0.334 & $25.634^{* *}$ \\
\hline 7 & $\begin{array}{c}-1.138^{* *} \\
(-1.503)\end{array}$ & - & - & - & - & - & - & $\begin{array}{l}-0.512 \\
(0.714)\end{array}$ & - & 0.236 & $29.541 * *$ \\
\hline 8 & $\begin{array}{l}0.731^{*} \\
(1.036)\end{array}$ & - & - & - & - & - & - & - & $\begin{array}{c}0.618 \\
(0.915)\end{array}$ & 0.317 & $25.732 * *$ \\
\hline 9 & $\begin{array}{l}0.329^{*} \\
(0.474)\end{array}$ & $\begin{array}{c}0.148 \\
(0.240)\end{array}$ & - & $\begin{array}{l}0.729^{*} \\
(0.904)\end{array}$ & $\begin{array}{c}0.345 \\
(0.519)\end{array}$ & - & - & $\begin{array}{c}-0.386 \\
(-0.437)\end{array}$ & $\begin{array}{c}0.514 \\
(0.625)\end{array}$ & 0.314 & $27.585^{* *}$ \\
\hline 10 & $\begin{array}{c}2.240 \\
(2.513)\end{array}$ & - & $\begin{array}{c}-0.254 * * \\
(-0.361)\end{array}$ & $\begin{array}{l}0.686^{*} \\
(0.734)\end{array}$ & $\begin{array}{c}0.317 \\
(0.416)\end{array}$ & - & $\begin{array}{c}-0.169 * * \\
(-0.206)\end{array}$ & - & - & 0.293 & $28.364 * *$ \\
\hline 11 & $\begin{array}{l}0.373^{*} \\
(0.431)\end{array}$ & $\begin{array}{c}0.142 \\
(0.169)\end{array}$ & $\begin{array}{l}-0.239^{*} \\
(-0.484)\end{array}$ & $\begin{array}{c}0.387^{* *} \\
(0.503)\end{array}$ & $\begin{array}{c}0.127 \\
(0.268)\end{array}$ & $\begin{array}{l}0.427 * \\
(0.514)\end{array}$ & $\begin{array}{c}-0.142 * * \\
(-0.371)\end{array}$ & $\begin{array}{c}-0.245 \\
(-0.475)\end{array}$ & $\begin{array}{c}0.501 \\
(0.672)\end{array}$ & 0.331 & $30.581 * *$ \\
\hline
\end{tabular}

Source: SEBON (2000/01-2017/18)

Note: $\quad$ **and * indicate significant at 1 percent and 5 percent level of significance. This table presents results of regression model designed to analyze the impact of eight firm fundamental variables on total financial leverage. Table also presents the value of F-statistic and Adjusted R-square of each model. The values in parenthesis are t-statistics.

Table 5 exhibits result of regression models. Model 1 shows regression coefficient of SIZE is 0.059 as per priori expected sign. However, regression coefficient is not statistically significant. SIZE has been further included in model9 and model11 with other explanatory variables to confirm its effect on total financial leverage. As exhibited in Table 5, all coefficients of regression models are not statistically significant. Result indicates use of total debt in Nepalese non-financial firms is not affected by their size of sales.

Similarly, model 2 is designed to examine effect of profitability on total financial leverage. Regression coefficient of profitability is negative as per priori expected sign and is statistically significant. Same result is observed in other two multivariate models 10 and 11. This result indicates profitable Nepalese non-financial firms borrow less to finance their assets. Coefficients of asset tangibility has been found positive and statistically significant both in univariate and multivariate models viz. in models 3, 9, 10 and 11.Further, all coefficients are significant which indicate that Nepalese non-financial firms with more tangible assets use more debt in their financial structure. 
Further, model 4 is designed to examine effect of growth opportunity on total financial leverage. Growth has positive coefficient as per priori expected sign (0.396). However, coefficient is not statistically significant. In addition to this, it has been further included in three multivariate models viz. in models 9,10 and 11. Results of multivariate analysis show positive but insignificant effect of growth opportunity on total financial leverage. This result indicates growth opportunity is irrelevant for use of debt by Nepalese non-financial firms. Model 5 shows relationship between earning variability and leverage. Earnings variability has positive impact on total financial leverage and it is statistically significant at 5 percent level. This result supports to the findings of Hsia (1981) but, contradicts with findings of Myers (1977), Booth et al. (2001), Titman and Wessels (1988). Thus, result of regression analysis indicates firms with higher level of leverage tend to make riskier investments in Nepalese firms.

Model 6 examines impact of liquidity on total financial leverage of Nepalese firm. Regression coefficient of liquidity has been found negative -0.172 . This relationship is further examined in two multivariate models 10 and 11. In all models, sign of coefficients have been found negative and statistically significant at 1 percent level. The result indicates firms with high liquidity tend to avoid raising external debt capital. Despite having negative coefficient of non-debt tax shield in univariate model 7 , multivariate models 9 and 11 as per priori expectation, all coefficients are statistically insignificant. This result indicates increase in non-debt tax shield will not have significant effect on use of total financial leverage in Nepalese non-financial firms. The coefficient of AGE has been found positive in all regression models 8, 9, and11 as per priori expected sign. However, all these coefficients are not statistically significant. Results indicate that age of firms has no effect on use of total financial leverage in Nepalese non-financial firms. Adj. $R^{2}$ of model 11 with inclusion of all explanatory variables is 0.331 which indicates predicting power of explanatory variables is 33.1 percent to explain financial leverage of Nepalese firms. F-statistics of all regression models are statistically significant at 1 percent level which implies the fitness of test of overall models.

\section{Conclusion}

This paper has been attempted to analyze nexus between firm fundamentals and financial leverage of Nepalese non-financial firms using descriptive and causal comparative research design for the study period 2000/01 - 2017/18. This study confirms that profitability, earning variability, liquidity are the major influencing factors of financial leverages in Nepalese nonfinancial firms. The paper reveals that short-term financial leverage is positively affected by growth and earning variability and negatively affected by profitability, asset tangibility, and liquidity. Similarly, long-term financial leverage is positively affected by size of sales, asset tangibility, earning variability and negatively affected by profitability and liquidity of Nepalese firms. Further, this study concludes that positive nexus of asset tangibility and earning variability with total financial leverage and negative effect of profitability and liquidity on total financial leverage of Nepalese non-financial firms. Finally, result of the study concludes that firm's non-debt tax shield and age have no significant impact on all types of financial leverage in Nepalese non-financial firms. 


\section{Implications of the study}

This paper concludes that firm fundamentals are dominant dimensions of financial leverage of non-financial firms in Nepal. Thus, future study could build on contextualized the effect of firm fundamentals on financial leverage of non-financial firms. From the policy perspective, greater emphasis is needed on firm fundamentals to maintain the optimal financial leverage in Nepalese non-financial firms. Similarly, this study may be useful to academics in research and teaching learning activities in the field of financial leverage by maintaining optimal capital structure of firms. Result of this paper would be helpful for financial managers and investors of firms to get various information of financial leverage to make sound capital structure and investment decisions for efficient utilization of various resources for smooth operation of business activities in Nepalese non-financial firms. Finally, results of this paper would be useful to policy makers for the formulation and implementation of business and financial leverage policies and strategies.

\section{References}

Akiny, O. J., \& Olagunju, A. (2013). Determinants of capital structure in Nigeria. International Journal of Innovation and Applied Studies, 3(4), 999-1005.

Antoniou, A., Guney, Y., \& Paudyal, K. (2002). Determinants of corporate capital structure: Evidence from European countries (Working Paper). University of Durham.

Arsov, S., \& Naumoski, A. (2016). Determinants of capital structure: An empirical study of companies from selected post-transition economies. Journal of Economics and Business, 34(1), 119-146.

Awan, A. G., \& Amin, M. S. (2014). Determinants of capital structure. European Journal of Accounting, Auditing and Finance Research, 2(9), 22-41.

Baral, K. J. (1996). Capital structure and cost of capital in public sector enterprises in Nepal (an unpublished Ph. D. Thesis). Faculty of Management, University of Delhi, Delhi.

Bhaduri, N. S. (2002). Determinants of corporate borrowing: Some evidence from the Indian corporate structure. Journal of Economics and Finance, 26(2), 200-215.

Bhat, R. K. (1980). Determinants of financial Leverage: Some further evidence. Chartered Accountant, 29(6), 451-456.

Booth, L., Aivazian, V., Demirguc-kunt, A., \& Maksimovic V. (2001). Capital structure in developing countries. The Journal of Finance, 56 (1), 87-130.

Bradley, M., Jarrel, G. A., \& Kim, E. H. (1984). On the existence of an optimal capital structure: Theory and evidence. The Journal of Finance, 39 (3), 857-880.

Chaplinsky, S., \& Niehaus, G. (1993). Do inside ownership and leverage share common determinants? Quarterly Journal of Business and Economics, 32(4), 51-65.

Chen, L., \& Chen, S. Y. (2011). How the packing order theory explains capital structure? Journal of International Management Studies, 6(2), 1-9. 
Danso, A., \& Adomako, S. (2014). The financing behavior of firms and financial crisis. Managerial Finance, 40(12), 1159-1174.

DeAngelo, H., \&Masulis, R. W. (1980). Optimal capital ctructure under corporate and personal taxation. Journal of Financial Economics, 8(1), 3-29.

Downs, T.W. (1993). Corporate leverage and nor-debt-tax shields: Evidence on crowding out. Financial Review, 28(4), 549-581.

Ezeoha, E.A. (2008). Firm size and corporate financial leverage choice in a developing economy: Evidence from Nigeria. The Journal of Risk Finance, 9(4), 351-364.

Fama, E. F. (1985). What is difference about banks? Journal of Monetary Economics, 15(1), 2939.

Fama E., \& French, K. (2002). Testing trade-off and pecking order predictions about dividend and debt. Review of Financial Studies, 15(1), 1-33.

Ferri, M. G., \& Jones, W. H.(1979). Determinants of financial structure: A new methodological approach. The Journal of Finance, 34 (3), 631-644.

Harris, M., \& Raviv, A. (1990). Capital structure and the informational role of debt. The Journal of Finance, 45 (2), 321-349.

Hsia, C. C. (1981). Coherence of the modern theories of finance. Financial Review, 16(1), 2742.

Javed, A. Y., \& Imad, Q. (2012). A decomposition analysis of capital structure: Evidence from Pakistan's manufacturing sector. The Lahore Journal of Economics, 17(1), 1-31.

Jensen, G. R., Solberg, D. P., \& Zorn, T. S. (1992). Simultaneous determination of insider ownership, debt and dividend policies. Journal of Financial Quantitative Analysis, 27(2), 247-263.

Jensen, M., \& Meckling, W. (1976).Theory of the firm: Managerial behavior, agency cost and ownership structure. Journal of Financial Economics, 3(4), 305-360.

Jensen, M. C. (1986). Agency cost of free cash flow, corporate finance and takeovers. American Economic Review, 76(2), 323-339

Jordan, J., Lowe, J. \& Taylor, P. (1998). Strategy and financial policy in UK small firms. Journal of Business Finance and Accounting, 25(1-2), 1-27.

Joshi, K. R. (2008).Capital structure management in Nepalese enterprises (an unpublished Ph. D. Dissertation). Faculty of Commerce, Vanaras Hindu University, Varanasi.

Khan, M., Shah, M. S., Hag, F. \& Shah, S. Z. (2014). Determinants of capital structure of nonfinancial companies of Pakistan. Journal of Poverty Investment and Development, 6, 2028.

Kim, E. H. (1978). A mean variance theory of optimal capital structure and corporate debt capacity. Journal of Finance, 33(1), 45-63.

Kim, W. S., \& Soreson, E. H. (1986). Evidence on the impact of the agency cost of debt in corporate debt policy. Journal of Financial and Quantitative Analysis, 21(2), 131-144. 
Kraus, A., \& Litzenberger, R. (1973). A state preference model of optimal financial leverage. Journal of Finance, 28(4), 911-922.

Modigliani, F., \& Miller, M. (1958). The cost of capital, corporation finance and the theory of investment. American Economic Review, 48(3), 261-297.

Modigliani, F., \& Miller, M. (1963). The corporate income taxes and the cost of capital, corporate finance and the theory of investment. American Economic Review, 53(3), 433-443.

Myers, S. C. (1977). Determinants of corporate borrowings. Journal of Financial Economics, 5(2), 147-175.

Myers, S. C. (1984). The capital structure puzzle. Journal of Finance, 39(3), 575-592.

Myers, S. C., \& Majluf, N. S. (1984).Corporate financing and investment decision when firms have information that investor do not have. Journal of Financial Economics, 13(2), 187- 221.

Noe, T. H. (1988). Capital structure and signaling game equilibria. The Review of Financial Studies, 1(4), 331-355.

Olayinka, A. (2011). The determinance of capital structure: Evidence from Nigerian panel data. African Economic and Business Review, 9(1), 1-16.

Ozkan, A. (2001). Determinants of capital structure and adjustment to long run target: Evidence from UK Company panel data. Journal of Business, Finance and Accounting, 28(1-2), 175198.

Pittman, J. A. (2002). The influence of firm maturation on tax-induced financing and investment behavior. The Journal of the American Tax Association, 24 (2), 35-59.

Rajan, R.G., \& Zingales, L. (1995). What do we know about Capital Structure? Some evidence from international Data. The Journal of Finance, 50(5), 1421-1460.

Singh, A., \& Hamid, J. (1992). Corporate financial structures in developing countries (Technical Paper No. 1). IFC, Washing DC.

Stulz, R., \& Johnson, H. (1985). An analysis of secured debt. Journal of Financial Economics, 14(4), 501-521.

Titman, S., \& Wessels, R. (1988). The determinants of capital structure choice. The Journal of Finance, 43(1), 1-17.

Wald, J. K. (1999). How firm characteristics affect capital structure, an international comparison. Journal of Financial Research, 22(2), 161-187.

Warner, J. B. (1977). Bankruptcy cost: Some evidence. The Journal of Finance, 32(2), 337-347.

Williamson, O. (1988). Corporate finance and corporate governance. Journal of Finance, 43(3), 567-591. 